\title{
Genetic Divergence Studies using Mahalanobis D Square Analysis in Sesame (Sesamum indicum L.) Germplasm
}

\author{
A. B. M. Sirisha ${ }^{1 *}$, S. K. Haseena Banu ${ }^{1}$ and R. Saritha ${ }^{2}$ \\ ${ }^{1}$ Department of Genetics and Plant Breeding, Agricultural Research Station, Yellamanchili, \\ Visakhapatnam District, Andhra Pradesh-531055, India \\ ${ }^{2}$ AcharyaN.G.Ranga Agricultural University, Guntur, Andhra Pradesh, India \\ *Corresponding author
}

\section{A B S T R A C T}

\section{Keywords \\ Sesame, Genotype, Genetic divergence, D square analysis, Clustering \\ Article Info \\ Accepted: \\ 20 July 2020 Available Online: 10 August 2020}

The present study was conducted during Kharif 2018 at Agricultural Research Station, Yellamanchili, Andhra Pradesh, India, comprising of 114 sesame genotypes evaluated for seven parameters viz., days to $50 \%$ flowering, plant height $(\mathrm{cm})$, branches per plant, capsules per plants, seeds per capsule, days to maturity and seed yield per plant (g). Analysis of variance showed highly significant differences among 114 genotypes for all the characters studied showing the presence of genetic variability among the materials studied. The maximum intercluster distance was recorded between cluster $\mathrm{V}$ \& cluster XI (2815.15) indicating the maximum divergence between the clusters. Among the relative contribution of the characters under study, the parameters days to maturity, number of branches per plant and number of capsules showed maximum contribution.

\section{Introduction}

Sesame (Sesamum indicum L.) belongs to the family pedaliaceae $(2 n=26)$. It is grown in subtropical and tropical countries. Sesame is an important oil seed crop. The sesame seeds are edible and used in confectionaries. Sesame seed oil has wide applications in pharmaceuticals, industries, cosmetics etc. Sesame is highly remunerative crop with low investment in farmer's point of view. The average productivity of sesame in India is 413 $\mathrm{kg} / \mathrm{ha}$ and world is $512 \mathrm{~kg} / \mathrm{ha}$ (FAO STAT 2020). Higher yields in sesame help to get high oil recovery and thus counter the heavy oil demand in the present scenario of the increasing population. The higher yield may be obtained adopting the improved varieties. At this juncture, in the development of varieties, identification of elite divergent genotypes is very essential. Diverse potential germplasm is the basis for any fruitful hybridization programme. Hybridization carried out between diverse parents results in development of high yielding varieties. To identify the diverse parents Mahalanobis D square analysis (Mahalanobis 1936) plays a critical role in identification of the diverse 
parents. In the present investigation, the germplasm lines under study are analysed with the Mahalanobis D square analysis which will result in diverse clusters. The parents from diverse clusters are utilised further in the hybridisation programme.

\section{Materials and Methods}

The present investigation was carried out during Kharif 2018 at Agricultural Research Station, Yellamanchili, Andhra Pradesh. The experimental site is located at $17.570^{\circ} \mathrm{N}$ and $82.847^{0} \mathrm{E}$. The experimental site is located 66 $\mathrm{km}$ away from Bay of Bengal. The type of soil is Sandy loam. The experiment was conducted with 114 genotypes laid in Randomized block design with two replications. Each plot consisted of two rows each of $4.5 \mathrm{~m}$ row length with $30 \times 15 \mathrm{~cm}$ spacing. Observations were recorded on five randomly selected plants for the seven parameters viz., days to $50 \%$ flowering, plant height $(\mathrm{cm})$, branches per plant, number of capsules per plant, number of seeds per capsule, days to maturity and seed yield per plant $(\mathrm{g})$. The mean data were used for the statistical analysis. The data is analysed using Mahalanobis $\mathrm{D}^{2}$ statistical analysis (Mahalanobis 1936). The grouping of genotypes into different clusters was done using the Tocher's method as described by Rao (1952). In the present study, PCA was performed on the correlation matrix of traits, thereby removing the effects of scale (Jackson, 1991).

\section{Results and Discussion}

Analysis of variance showed highly significant differences among the 114 sesame genotypes, indicating the presence of genetic variability for the entire characters understudy. Based on Mahalanobis D square analysis all the genotypes grouped into eleven (11) clusters. Among the eleven clusters, cluster IX was the biggest cluster accommodating 25 sesame genotypes (Table 1). The intracluster distances values range from 0 (cluster IV) to 117.8 (cluster I) (Table 2) (Rodge et al., 2003). The minimum inter cluster distance values recorded was 82.73 (between class VI and class VII). The maximum intercluster distance value recorded was 2815.15 between cluster V and cluster XI followed by cluster $\mathrm{V}$ and cluster IX (2336.81). Except cluster II all the clusters recorded high inter cluster distance values with cluster XI. Based on the parameters in the breeding programme, the genotypes may be selected from the clusters V, XI and IX. The results are in accordance with Jadhav and Mohrir (2013), Tanwar and Bisen (2018).

The genotypes from cluster V, cluster XI and cluster IX may be adopted in the hybridization program which will result variability in segregating population (Table 1). The parameters days to maturity contributed $(63.72 \%)$ followed by number of branches per plant (15. 62\%), number of capsules per plant (14. $50 \%$ ), days to $50 \%$ flowering $(2.39 \%)$, seed yield per plant $(2.02$ $\%)$, seeds per capsule $(0.98 \%)$, plant height $(0.78 \%)$ showed maximum contribution towards total genetic divergence (Table 3). The results are in accordance with Mandakini et al., 2020. The importance of contribution of yield components towards divergence can be judged by the group means of the seven characters (Table 4). The cluster $X$ recorded desirable low mean values for days to $50 \%$ flowering (36) and cluster VIII for days to maturity (79.0). The highest mean values are recorded for cluster VIII recorded for the character plant height $(168.67 \mathrm{~cm})$, cluster VII for number of branches per plant (6.5), Cluster IV recorded high mean values for number of capsules per plants (79), cluster VII for highest number of seeds per capsule (81). The Cluster IV recorded high mean values for seed yield per plant $(3.78 \mathrm{~g}$ ) (Table $2)$. The results are in accordance with the reports of Mandakini et al., 2020, Soundarya 
et al., 2017, Tripati et al., (2013), Swathy et al., (2018).

\section{Principal component analysis}

In the present study, principal component analysis identified four principal components contributing 85.31 percentage of cumulative variance (Table 4). The first three principal components with eigenvalues more than one contribute more towards the total variability. The principal components less than one were considered non-significant. The first principal component contributed maximum towards variability 36.44 percent. The characters days to maturity (0.40) and days to $50 \%$ flowering $(0.29)$ has positive loading. The second principal component contributed $21.93 \%$ to maximum variability with seed yield per plant (g) (0. 52), days to maturity (0.50), days to
$50 \%$ flowering (0.22), number of seeds for capsule (0.15)number of capsules per plant (0.13) and number of branches per plant (0.08) showed positive loading. The third principal component contributed (14.82\%) of total variability and positively loaded with number of branches per plant ( 0.80$)$; days to $50 \%$ flowering (0.51) plant height $(0.20)$; number of seeds per capsule (0.14) and days to maturity (0.04). The forth principal component contributed $12.11 \%$ of total variability with days to $50 \%$ flowering (0.55), number of capsules per plant (0.36); seeds per capsule (0.19) showed positive loading effects (Table 4). The reports are accordance with Swathy et al., (2018), Soundharya et al., 2017, Tripati et al., (2013), Menzir (2012), Solanki and Gupta (2003).

Table.1 Clustering of 114 genotypes of sesame (Sesamum indicum L.) as per Mahalanobis $\mathrm{D}^{2}$ analysis

\begin{tabular}{|c|c|c|c|}
\hline S.No & Cluster No. & No.of genotypes & Genotypes in the cluster \\
\hline 1 & I & 7 & $\begin{array}{l}\text { PT-10, IC-376985, RT-347, IC-323187, NIRMALA, TKG-306, } \\
\text { YLM-66, }\end{array}$ \\
\hline 2 & II & 8 & LT-10, RT-103, DSS-9,RT-127, GT-3, TKG-55, GT-2, GT-5 \\
\hline 3 & III & 12 & $\begin{array}{l}\text { MT-10-11-13, IC 131607, OSC-207, MT-13-8-2, TKG-501, TKG-22, } \\
\text { PT-2, RT-351, RT-46, TKG-560, RT-168, AT-249 }\end{array}$ \\
\hline 4 & IV & 5 & OSC-75, KSAS-06/97, NSKMS-162, NSKMS-153, NSKMS-176 \\
\hline 5 & V & 1 & NSKMS-40 \\
\hline 6 & VI & 7 & RT-346, VZM-6, VZM-3, VZM-5, VSP-6, VZM-2, VZM-4 \\
\hline 7 & VII & 15 & $\begin{array}{l}\text { DCB-1794, IC-260760, VSP-7, VZM-15, VZM-13, YLM-17, YLM- } \\
\text { 11, MT-10-8, EC-370735, EC-355653, EC-370360, Madhavi, EC- } \\
\text { 376985, VZM-2, Gouri }\end{array}$ \\
\hline 8 & VIII & 12 & $\begin{array}{l}\text { IC-243309, IC-215527, IC-312267, VZM-14, IC-204185, IC-260713, } \\
\text { IC-127325, EC-377204, SKL-14, IC-179934,, VZM-7, EC-377169 }\end{array}$ \\
\hline 9 & IX & 25 & $\begin{array}{l}\text { IC-205247, IC-541229, VZM-11, VSP-16, SKL-18, IC-277001, } \\
\text { EC370686, VSP-2, VZM-8, VSP-1, SKL-19, VSP-12, VSP-4, SKL- } \\
\text { 18, VSP-5, VZM-1, VZM-9, SKL-15, VSP-11, VSP-8, VSP-10, } \\
\text { VZM-10, VSP-14, VSP-9 }\end{array}$ \\
\hline 10 & $\mathrm{X}$ & 12 & $\begin{array}{l}\text { JCS-1902, SKL-17, TMV-3, SI-5354, SI-75, T BROWN, IC-123295, } \\
\text { SKL-10, IC-208569, SKL-1, SKL-2, SKL-12 }\end{array}$ \\
\hline 11 & $\mathrm{XI}$ & 10 & $\begin{array}{l}\text { SKL-4, SKL-9, SKL-7, SKL-13, SKL-3, SKL-6, SKL-8, SKL-5, } \\
\text { SKL-11, JTS-8 }\end{array}$ \\
\hline
\end{tabular}


Table.2 Inter and intra cluster distances in sesame (Sesamum indicum L.) of 114 genotypes

\begin{tabular}{|c|c|c|c|c|c|c|c|c|c|c|c|}
\hline & $\begin{array}{c}\text { Clust } \\
\text { er I }\end{array}$ & $\begin{array}{c}\text { Cluster } \\
\text { II }\end{array}$ & $\begin{array}{c}\text { Cluster } \\
\text { III }\end{array}$ & $\begin{array}{c}\text { Cluste } \\
\text { r IV }\end{array}$ & $\begin{array}{c}\text { Cluster } \\
\text { V }\end{array}$ & $\begin{array}{c}\text { Cluster } \\
\text { VI }\end{array}$ & $\begin{array}{c}\text { Cluster } \\
\text { VII }\end{array}$ & $\begin{array}{c}\text { Cluster } \\
\text { VIII }\end{array}$ & $\begin{array}{c}\text { Cluster } \\
\text { IX }\end{array}$ & $\begin{array}{c}\text { Cluster } \\
\text { X }\end{array}$ & $\begin{array}{c}\text { Cluster } \\
\text { XI }\end{array}$ \\
\hline Cluster I & 117.8 & 312.25 & 248.59 & 464.54 & 1018.58 & 371.80 & 241.92 & 520.18 & 565.11 & 624.07 & 1150.26 \\
& 2 & & & & & & & & & & \\
\hline Cluster II & & 64.53 & 312.58 & 365.14 & 1368.76 & 202.41 & 230.46 & 547.39 & 409.03 & 345.89 & 747.57 \\
\hline Cluster III & & & 66.11 & 128.88 & 734.79 & 551.07 & 478.57 & 925.91 & 877.05 & 726.19 & 1400.96 \\
\hline Cluster IV & & & 69.17 & 685.34 & 853.29 & 761.53 & 1328.40 & 1229.91 & 1021.94 & 1785.61 \\
\hline Cluster V & & & & 0.00 & 2044.09 & 1691.05 & 2058.27 & 2336.81 & 1781.85 & 2815.15 \\
\hline Cluster VI & & & & & 34.05 & $\mathbf{8 2 . 7 3}$ & 241.43 & 118.88 & 276.26 & 454.85 \\
\hline Cluster VII & & & & & & 50.47 & 180.35 & 139.04 & 280.80 & 522.95 \\
\hline Cluster VIII & & & & & & & 81.30 & 132.10 & 256.24 & 333.96 \\
\hline Cluster IX & & & & & & & & & 60.57 & 224.30 & 258.31 \\
\hline Cluster X & & & & & & & & & & 96.41 & 219.09 \\
\hline Cluster XI & & & & & & & & & & & 89.55 \\
\hline
\end{tabular}

Table.3 Contribution of different characters towards genetic divergence as per $\mathrm{D}^{2}$ analysis in Sesame (Sesamum indicum L.)

\begin{tabular}{|l|c|c|}
\hline Source & Contribution \% & Times Ranked 1st \\
\hline 1 Days to 50 \% Flowering & 2.39 & 154.000 \\
\hline 2 Plant Height (cm) & 0.78 & 50.000 \\
\hline 3 Number of Branches/ Plant & 15.62 & 1006.000 \\
\hline 4 Number of Capsules/ Plant & 14.50 & 934.000 \\
\hline 5 Number of Seeds/ Capsule & 0.98 & 63.000 \\
\hline 6 Days to Maturity & 63.72 & 4104.000 \\
\hline 7 Seed Yield Per Plant (g) & 2.02 & 130.000 \\
\hline
\end{tabular}

Table.4 Mean values of the characters of clusters of Sesame (Sesamum indicum L.) of 114 genotypes

\begin{tabular}{|l|c|c|c|c|c|c|c|}
\hline & $\begin{array}{c}\text { Days to 50 } \\
\text { \% } \\
\text { Flowering }\end{array}$ & $\begin{array}{c}\text { Plant } \\
\text { Height } \\
\text { cm }\end{array}$ & $\begin{array}{c}\text { Branches/ } \\
\text { Plant }\end{array}$ & $\begin{array}{c}\text { Number of } \\
\text { Capsules/ } \\
\text { Plant }\end{array}$ & $\begin{array}{c}\text { Number of } \\
\text { Seeds/ } \\
\text { Capsule }\end{array}$ & $\begin{array}{c}\text { Days to } \\
\text { Maturity }\end{array}$ & $\begin{array}{c}\text { Seed Yield } \\
\text { Per Plant (g) }\end{array}$ \\
\hline 1 Cluster & 39 & 151.31 & 4.6 & 29 & 30 & 86 & 2.66 \\
\hline $\mathbf{2}$ Cluster & 37 & 166.47 & 5.0 & 35 & 36 & 80 & 2.48 \\
\hline 3 Cluster & 37 & 156.84 & 5.7 & 78 & 79 & 81 & 2.71 \\
\hline $\mathbf{4}$ Cluster & 37 & 147.15 & 5.6 & $\mathbf{7 9}$ & 80 & 83 & $\mathbf{3 . 7 8}$ \\
\hline $\mathbf{5}$ Cluster & 38 & 155.20 & 5.1 & 66 & 68 & 83 & 3.03 \\
\hline 6 Cluster & 38 & 154.83 & 5.7 & 73 & 73 & 82 & 2.59 \\
\hline 7 Cluster & 38 & 154.32 & $\mathbf{6 . 5}$ & 77 & $\mathbf{8 1}$ & 86 & 2.69 \\
\hline 8 Cluster & 38 & $\mathbf{1 6 8 . 6 7}$ & 5.5 & 61 & 61 & $\mathbf{7 9}$ & 2.62 \\
\hline 9 Cluster & 39 & 165.24 & 5.4 & 61 & 64 & 81 & 2.16 \\
\hline 10 Cluster & $\mathbf{3 6}$ & 149.84 & 4.4 & 38 & 39 & 84 & 2.20 \\
\hline 11 Cluster & 44 & 154.31 & 4.8 & 15 & 13 & 87 & 1.31 \\
\hline
\end{tabular}


Table.5 Eigen values, per cent and cumulative variance, factors loading of different characters in sesame (Sesamum indicum L.)

\begin{tabular}{|l|r|r|r|r|}
\hline & \multicolumn{1}{|c|}{ PC $_{\mathbf{1}}$} & \multicolumn{1}{|c|}{ PC $_{\mathbf{2}}$} & \multicolumn{1}{|c|}{$\mathbf{P C}_{\mathbf{3}}$} & \multicolumn{1}{|c|}{$\mathbf{P C}_{\mathbf{4}}$} \\
\hline Eigen Value (Root) & 2.55 & 1.53 & 1.03 & 0.84 \\
\hline \% Var. Exp. & 36.44 & 21.93 & 14.82 & 12.11 \\
\hline Cum. Var. Exp. & 36.44 & 58.37 & 73.19 & $\mathbf{8 5 . 3 1}$ \\
\hline Days to 50 \% Flowering & 0.29 & 0.22 & 0.51 & 0.55 \\
\hline Plant Height cm & -0.03 & -0.63 & 0.20 & -0.30 \\
\hline Branches/ Plant & -0.26 & 0.08 & 0.80 & -0.31 \\
\hline Capsules/ Plant & -0.55 & 0.13 & -0.19 & 0.36 \\
\hline Seeds/ Capsule & -0.59 & 0.15 & 0.14 & 0.19 \\
\hline Days to Maturity & 0.40 & 0.50 & 0.04 & -0.12 \\
\hline Seed Yield Per Plant (g) & -0.20 & 0.52 & -0.13 & -0.57 \\
\hline
\end{tabular}

$\mathrm{PC}=$ Principal Component

In conclusions the present investigation was carried out for studying the divergence between the 114 genotypes. Mahalanobis D square analysis is a useful tool for the plant breeders assisting for fruitful for hybridization programme. The present study revealed the grouping of genotypes into eleven clusters using Mahalanobis $\mathrm{D}^{2}$ analysis. Among which the clusters $\mathrm{V}$ and XI are farthest from each other followed by cluster $\mathrm{V}$ and IX. The parents from these clusters may be utilised in hybridization programme for obtaining the desirable progeny for further selection process.

\section{Acknowledgement}

The authors are highly thankful for the Acharya N.G. Ranga Agricultural University for providing the funding for the experiment and to NBPGR, New Delhi for supply of the germplasm under study.

\section{References}

Jackson, J. E. 1991. A User's Guide to Principal Components. John Wiley and Sons Inc., New York.

Jadhav, R.S. and Mohrir, M.N., 2013. Genetic divergence analysis in sesame (Sesamum indicum L.). Electronic Journal of Plant Breeding, 4(1), pp.1090-1092.

Mahalanobis, P.C., 1936. The generalized distance in statistics. Proceeding of Indian National Institute of Science 2: 49-55.

Mandakini K, Baisakh B, Dash M, Tripathy SK. Study of genetic diversity based on quantitative traits in sesame. The Pharma Innovation Journal, 2020; 9(7): 186-190

Menzir, A., 2012. Phenotypic variability, divergence analysis and heritability of characters in sesame (Sesamum indicum L.) genotypes. Nature and Science, 10 (10), pp.117-126.

Rao, C.R., 1952. Advanced statistical methods in biometrical research. John Wiley and Sons INC., New York. 357363.

Rodge, P.R.I.T.I., Sakhare, S.B. and Reddy, P.S., 2003.D^ 2 Analysis in sesame (Sesamum indicum L.). Madras Agricultural Journal, 90, pp.617-620.

Solanki, Z. S. and Gupta, D. 2003. Variability and character association among quantitative characters of sesame, Journal Oilseeds Res. 20: 276-277.

Soundharya, B. Hemalatha, V. Rani T.S., and Edukondalu, B. 2017. Genetic divergence studies in sesame (Sesamum 
indicum L.) genotypes. Int. J. Curr. Microbiol. Appl. Sci., 6(9): 2615-2619

Swathy, V., Premnath, A., Viswanathan, P.L., Raveendran, M. and Manonmani, S., 2018. Determination of genetic divergence based on morphological traits in sesame (Sesamum indicum L.). Electronic Journal of Plant Breeding, 9 (2), pp.747-752.

Tanwar, A. and Bisen,R. 2018. Genetic diversity analysis in sesame (Sesamum indicum L.) germplasm based on morphological and quality traits. Electron. J. Plant Breed., 9(1): 9-17.

Tripathi, A.N.J.A.Y., Bisen, R.A.J.A.N.I., Ahirwal, R.P., Paroha, S., Sahu, R. and Ranganatha, A.R.G., 2013. Study on genetic divergence in sesame (Sesamum indicum L.) germplasm based on morphological and quality traits. The Bioscan, 8(4), pp.1387-1391.

\section{How to cite this article:}

Sirisha, A. B. M., S. K. Haseena Banu and Saritha, R. 2020. Genetic Divergence Studies using Mahalanobis D Square Analysis in Sesame (Sesamum indicum L.) Germplasm. Int.J.Curr.Microbiol.App.Sci. 9(08): 2224-2229. doi: https://doi.org/10.20546/ijcmas.2020.908.255 